\title{
First Report of an SH2D1A Mutation Associated with X-Linked Lymphoproliferative Disease in Turkey
}

\author{
Türkiye'den Bildirilen Ilk X'e Bağı Lenfoproliferatif Hastalık Ilişkili SH2D1A Mutasyonu \\ Olgusu
}

\author{
(D) Selman Kesici ${ }^{1}$, (D) Ebru Yılmaz Keskin², (D) Samuel C.C. Chiang ${ }^{3}$, (D) Çiğdem Seher Kasapkara ${ }^{4}$, (D) Takuya Sekine ${ }^{3}$, (D) Meltem Akçaboy ${ }^{5}$, \\ (D) Ali Fettah ${ }^{6}$, (D) Yenan T. Bryceson ${ }^{3}$ \\ ${ }^{1}$ Dr. Sami Ulus Maternity and Children's Health and Diseases Training and Research Hospital, Clinic of Pediatric Intensive Care, Ankara, Turkey \\ ${ }^{2}$ Süleyman Demirel University Faculty of Medicine, Department of Pediatric Hematology and Oncology, Isparta, Turkey \\ ${ }^{3}$ Karolinska University Hospital Huddinge, Karolinska Institute, Center for Hematology and Regenerative Medicine, Department of Medicine, \\ Stockholm, Sweden \\ ${ }^{4}$ Dr. Sami Ulus Maternity and Children's Health and Diseases Training and Research Hospital, Clinic of Pediatric Metabolism and Nutrition, \\ Ankara, Turkey \\ ${ }^{5}$ Dr. Sami Ulus Maternity and Children's Health and Diseases Training and Research Hospital, Clinic of Pediatrics, Ankara, Turkey \\ ${ }^{6}$ Dr. Sami Ulus Maternity and Children's Health and Diseases Training and Research Hospital, Clinic of Pediatric Hematology and Oncology, \\ Ankara, Turkey
}

To the Editor,

X-linked lymphoproliferative disease (XLP) is a rare disorder characterized by an extreme vulnerability to EpsteinBarrvirus (EBV) infection, frequently resulting in hemophagocytic lymphohistiocytosis (HLH) [1]. XLP-1, its more common subtype, is caused by defects in the SH2D1A gene that encodes the signaling lymphocyte activation molecule-associated protein (SAP), which regulates the activation of T lymphocytes [2], whereas XLP-2 is caused by mutations in the XIAP gene, also known as BIRC4 [3].

We present here an XLP-1 patient with a family history of the death of multiple male children, who presented with EBVtriggered fatal HLH. To our knowledge, this is the first report of an SH2D1A mutation from Turkey.

Case: The 19-month-old male patient, admitted with the complaints of fever and abdominal distention, had pale appearance, fever (body temperature: $39.5{ }^{\circ} \mathrm{C}$ ), dyspnea, tachycardia, abdominal distention, and hepatosplenomegaly. Laboratory findings are summarized in Table 1.

In the family history, the death of a 2-year-old male sibling with the clinical diagnosis of HLH and of five young male children of unknown etiology among maternal relatives was noted (Figure 1).

The patient received intravenous immunoglobulin. However, in the follow-up, fever recurred and his general condition worsened. Bone marrow aspiration revealed hemophagocytosis. Therefore, the patient fulfilled the HLH diagnostic criteria. Plasma exchange was performed. Blood products, antimicrobials, and supportive therapeutic agents were used as indicated.

The results of EBV serologic testing and polymerase chain reaction were both reported as positive. On the $6^{\text {th }}$ hospitalization day, the HLH-2004 protocol treatment was initiated, and rituximab therapy was planned. Continuous veno-venous hemodialysis was performed. However, the vital signs of the patient deteriorated further and active gastrointestinal bleeding was observed. The patient died on the $10^{\text {th }}$ day of hospitalization.

In the cytotoxic lymphocyte activity analysis, low SAP expression in addition to signs of severe immunoactivation was detected (Figure 1). In the genetic analysis performed in the Clinical Genetics Unit of Karolinska University Hospital, Stockholm, Sweden, the c.163C $>$ T (p.Arg55Ter) mutation in the SH2D1A gene, described previously as pathologic [4], was identified (Figure 1). Genetic counseling was provided to the family. This letter was written after receiving informed consent from the parents.

We report here an XLP-1 case in which the patient presented with EBV-associated HLH. Although no genetic analysis was performed among the male relatives of the patient lost previously in childhood, XLP-1 seems to be the underlying cause in those children as well.

In XLP cases, the most common clinical manifestation is fulminant infectious mononucleosis (frequency: $58 \%$, survival: $4 \%$ ). Death is generally attributable to liver failure with hepatic 


\begin{tabular}{|c|c|}
\hline Hemoglobin (g/L) & 76 (NR: 98-134) \\
\hline White blood cells $\left(10^{3} / \mu \mathrm{L}\right)$ & 23.04 (NR: 5-14.8) \\
\hline Platelets $\left(10^{3} / \mu \mathrm{L}\right)$ & 169 (NR: 150-400) \\
\hline Direct Coombs & Negative \\
\hline Ferritin (ng/mL) & $841^{*}(\mathrm{NR}: 12-150)$ \\
\hline Lactate dehydrogenase (IU/L) & 757 (NR: 140-304) \\
\hline Albumin (g/dL) & 2.6 (NR: $3.1-4.8$ ) \\
\hline Serum sodium (mEq/L) & 128 (NR: 135-143) \\
\hline Aspartate aminotransferase (IU/L) & $354(N R:<48)$ \\
\hline Alanine aminotransferase (IU/L) & 178 (NR: 0-39) \\
\hline Bilirubin (total/direct) (mg/dL) & 2.0/1.1 (NR: 0-2.0/0-0.5) \\
\hline Triglyceride (mg/dL) & 320 (NR: $30-100)$ \\
\hline Prothrombin time (s) & 20.3 (NR: 10.0-14.7) \\
\hline Activated partial thromboplastin time (s) & 38.7 (NR: 22.0-34.0) \\
\hline Fibrinogen (mg/dL) & 130 (NR: 170-350) \\
\hline D-dimer (ng/mL) & 4,658 (NR: 0-550) \\
\hline Immunoglobulin M (mg/dL) & 455 (NR: 72-212) \\
\hline Immunoglobulin $\mathrm{G}$ (mg/dL) & 1,620 (NR: $658-1,460)$ \\
\hline Immunoglobulin A (mg/dL) & 347 (34-89) \\
\hline C-reactive protein $(\mathrm{mg} / \mathrm{L})$ & 60 (NR: 0-4) \\
\hline EBV VCA IgM & Positive \\
\hline EBV PCR & $\begin{array}{l}\text { Positive (526,736 copies/ } \\
\mathrm{mL} \text { ) }\end{array}$ \\
\hline $\begin{array}{l}\text { *Serum ferritin rose to } 28,321 \mathrm{ng} / \mathrm{mL} \text { on the } 5^{\text {th }} \text { hosp } \\
\text { NR: Normal range, EBV: Epstein-Barr virus, PCR: poly } \\
\text { capsid antigen, IgM: immunoglobulin M. }\end{array}$ & $\begin{array}{l}\text { italization day. } \\
\text { merase chain reaction, VCA: viral }\end{array}$ \\
\hline
\end{tabular}

encephalopathy or bone marrow failure with fatal hemorrhages in various organs [5]. The only curative treatment of XLP is hematopoietic stem cell transplantation [6].

In our case, the HLH-2004 protocol, initiated on the $6^{\text {th }}$ hospitalization day, did not prevent the deterioration of the patient's clinical status. Rituximab therapy has been reported to successfully induce remission in some cases of $\operatorname{XLP}[7,8]$. Unfortunately, our patient was lost before we could start rituximab therapy.

Establishment of the genetic diagnosis in male children suspected to have XLP will enable valuable genetic counseling.

Keywords: Lymphoproliferative disease, Hemophagocytosis, Epstein-Barr virus

Anahtar Sözcükler: Lenfoproliferatif hastalık, Hemofagositoz, Epstein-Barr virüsü

Conflict of Interest: The authors of this paper have no conflicts of interest, including specific financial interests, relationships, and/or affiliations relevant to the subject matter or materials included.
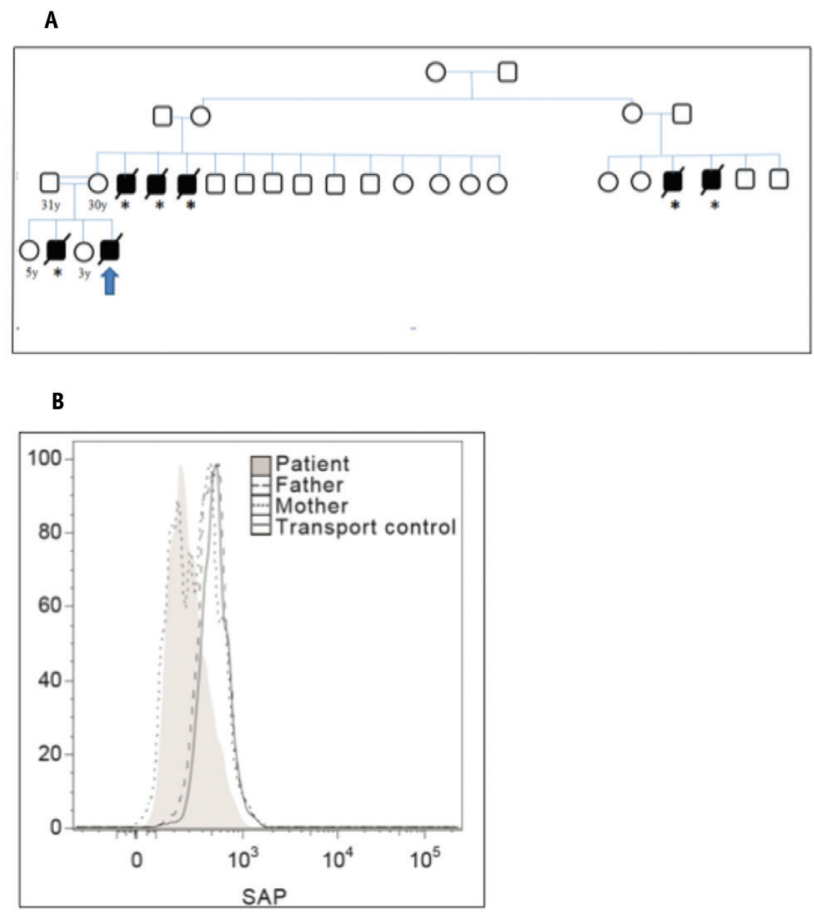

C

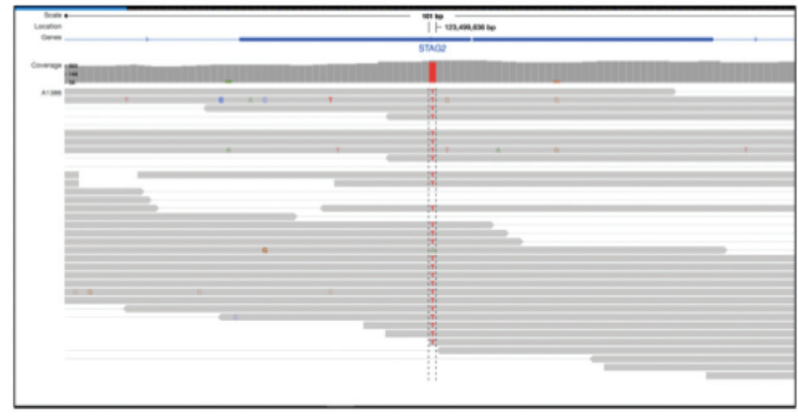

Figure 1. A) Pedigree of the family demonstrating loss of six male children, compatible with $\mathrm{X}$-linked recessive inheritance of disease. *All of the designated deaths occurred between 1 and 3 years of age. The propositus is indicated with an arrow; B) The levels of signaling lymphocyte activation molecule-associated protein (SAP) expression on dim natural killer cells of the patient and the parents by intracellular SAP analysis; C) Identification of the c.163C>T (p.Arg55Ter) mutation in the SH2D1A gene by sequencing analysis in the index case.

\section{References}

1. Sumegi J, Huang D, Lanyi A, Davis JD, Seemayer TA, Maeda A, Klein G, Seri M, Wakiguchi H, Purtilo DT, Gross TG. Correlation of mutations of the SH2D1A gene and Epstein-Barr virus infection with clinical phenotype and outcome in X-linked lymphoproliferative disease. Blood 2000;96:3118-3125.

2. Coffey AJ, Brooksbank RA, Brandau O, Oohashi T, Howell GR, Bye JM, Cahn AP, Durham J, Heath P, Wray P, Pavitt R, Wilkinson J, Leversha M, Huckle E, Shaw-Smith CJ, Dunham A, Rhodes S, Schuster V, Porta G, Yin L, Serafini P, Sylla B, Zollo M, Franco B, Bolino A, Seri M, Lanyi A, Davis JR, Webster D, Harris A, Lenoir G, de St Basile G, Jones A, Behloradsky BH, Achatz H, Murken J, Fassler R, Sumegi J, Romeo G, Vaudin M, Ross MT, Meindl A, Bentley DR. Host response to EBV infection in X-linked lymphoproliferative disease results from mutations in an $\mathrm{SH} 2$-domain encoding gene. Nat Genet 1988;20:129-135. 
3. Rigaud S, Fondanèche MC, Lambert N, Pasquier B, Mateo V, Soulas P, Galicier $L_{1}$, Rieux-Laucat F, Revy P, Fischer A, de Saint Basile G, Latour S. XIAP deficiency in humans causes an $\mathrm{X}$-linked lymphoproliferative syndrome. Nature 2006;444:110-114.

4. Lappalainen I, Giliani S, Franceschini R, Bonnefoy JY, Duckett C, Notarangelo LD, Vihinen M. Structural basis for SH2D1A mutations in X-linked lymphoproliferative disease. Biochem Biophys Res Commun 2000;269:124130.

5. Lanzkowsky P, Lipton JM, Fish JD. Lanzkowsky's Manual of Pediatric Hematology and Oncology, 6th ed. New York, Academic Press, 2016.
6. Patiroglu T, Akar HH, Unal E, Ozdemir MA, Karakukcu M. Hematopoietic stem cell transplant for primary immunodeficiency diseases: a single-center experience. Exp Clin Transplant 2017;15:337-343.

7. Milone MC, Tsai DE, Hodinka RL, Silverman LB, Malbran A, Wasik MA, Nichols KE. Treatment of primary Epstein-Barr virus infection in patients with X-linked lymphoproliferative disease using B-cell-directed therapy. Blood 2005;105:994-996.

8. Lee TL, Law HKW, Chan GCF, Ha SY, Ho MHK, Chan KW, Lau YL. Successful treatment of X-linked lymphoproliferative disease (XLP) with anti-CD20 monoclonal antibody (rituximab) followed by mismatched unrelated cord blood transplantation. Hong Kong J Paediatr 2006;11:210-214.

\title{
Intracranial Bleeding in a Female Hemophilia Patient: Molecular Analysis of the Factor 8 Gene and Determination of a Novel Mutation
}

\author{
Intrakraniyal Kanama ile Başvuran Hemofili A Olgusu: Yeni Bir Mutasyonun Moleküler Olarak \\ Tanımlanması
}

\author{
(D) Burçak Tatlı Güneş ${ }^{1}$, (D) Zühal Önder Siviş ${ }^{1}$, (D) Eda Ataseven ${ }^{1}$, (D Barış Malbora ${ }^{1}$, (D Meral Türker ${ }^{1}$, (D) Fatma Burcu Belen ${ }^{2}$, \\ (D) Berna Atabay ${ }^{1}$, (D) Tahir Atik ${ }^{3}$, (D) Esra Işık ${ }^{3}$, (D) Ferda Özkınay ${ }^{3}$ \\ ${ }^{1}$ Izmir Tepecik Training and Research Hospital, Clinic of Pediatric Hematology, Izmir, Turkey \\ ${ }^{2}$ Başkent University Faculty of Medicine, Department of Pediatric Hematology, Ankara, Turkey \\ ${ }^{3}$ Ege University Faculty of Medicine, Department of Pediatric Genetics, Izmir, Turkey
}

To the Editor,

An 11-month-old female patient was admitted to the emergency department with right occipital fracture and epidural hematoma. The father had severe hemophilia A and the parents were cousins. Laboratory tests revealed normal complete blood count and prolonged activated partial thromboplastin time. Mixing test results were normalized after mixing with normal plasma. After plasma samples were collected for further diagnostic tests, fresh frozen plasma and dexamethasone were administered. The factor VIII level was $0.1 \%, 35 \%$, and $0.5 \%$ for the patient, mother, and father, respectively. The patient's von Willebrand factor (VWF) level was $128 \mathrm{IU} / \mathrm{mL}$, VWF:Ricof was $110 \mathrm{IU} / \mathrm{mL}$, collagen ADP was 110 (reference: 71-118) s, and collagen epinephrine was 98 (reference: 85-165) s. Intron 22 inversion was investigated with the IS-PCR method and was found to be normal. Whole-genome analysis including all exonic regions of the F8 gene (NM_000132.3) was conducted and the homozygous c.608T>C (L203P) mutation was found.
This mutation was not previously reported. As this variant was not reported in any exome databases (ExAC, EVS) and as it was shown to be the cause of the disease in at least three in silico protein modeling programs, the mutation was considered as a novel mutation causing hemophilia A ("probably damaging" with 0.987 PolyPhen2 score, "disease causing" with 0.999 MutationTaster score, and "damaging" with 0 SIFT score). The mutation was also confirmed by Sanger sequencing (Figure 1). Plasma-derived FVIII at 2x500 IU/day was administered for 14 days followed by $300 \mathrm{IU} /$ week prophylaxis. Inhibitor screening at the $5^{\text {th }}$ and $10^{\text {th }}$ exposure days was negative.

Hemophilia $A$ is rarely seen in female patients due to skewed inactivation of the $X$ chromosome leading to inactivation of the wild-type $X$ chromosome, anomalies like Turner syndrome, or translocations, as well as homozygous/compound heterozygous mutations for hemophilia $A[1,2,3,4,5]$. The karyotype analysis of our patient revealed $46, X X$. The patient and the father were hemizygous and mother was heterozygous for the c.608T>C 